\title{
Fremtiden for Iraks arabiske sunnimuslimer
}

\section{Helle Lykke Nielsen}

Iraks sunnimuslimer har om nogen måttet betale prisen for krigen i Irak. Efter i flere hundrede år at have tilhørt Iraks magtelite mistede de i 2003 deres magtposition og blev reduceret til en blandt flere minoriteter i Irak. Hvordan er det gået dem siden Saddamstyrets fald, og hvordan tegner fremtiden sig for dem?

Saddamstyrets fald i 2003 var på mange måder en katastrofe for Iraks arabiske sunnimuslimer. I flere hundrede år havde de siddet på magten i Irak, først under osmannerne frem til Første Verdenskrig og siden i den irakiske nationalstat, hvor de udgjorde rygraden i militæret, efterretningstjenesterne og partiapparatet. Selv om de talmæssigt var en minoritet - som tommelfingerregel regner man med, at de udgør omkring 20 procent af befolkningen, men ingen ved det helt nøjagtigt - formåede de effektivt at underlægge sig resten af den irakiske befolkning.

Men i 2003 var det slut: Den amerikanske invasion fjernede effektivt den sunnimuslimske ledelse med Saddam i spidsen, opløste den irakiske hær med tilhørende efterretningstjenester og forbød Bathpartiet. Det sunnidominerede irakiske magtapparat faldt sammen, og de arabiske sunnimuslimer blev reduceret til en minoritet, der talmæssigt blot var lidt større end kurderne, som hovedsageligt også er sunnimuslimer, men etnisk ikke er arabere.

Det var selvsagt ikke alle arabiske sunnimuslimer, der var en del af Saddams magtapparat. Mange var slet ikke aktive i partiet, endsige støttede hans magtpolitik, og nogle modarbejdede endda styret i en så- 
dan grad, at de var nødt til at gå i eksil, hvis de ikke ville miste livet eller rådne op i et irakisk fængsel.

Alligevel var det som hovedregel en fordel at tilhøre gruppen af arabiske sunnimuslimer under Saddam, for det gav lettere adgang til velbetalte job i militæret og efterretningstjenesterne, højtstående embedsfunktioner i Bathpartiet og de goder, der fulgte med i form af høj løn, gode boligforhold, lettere adgang til gode skoler for børnene, etc. Med invasionen forsvandt dette eksistensgrundlag som dug for solen og ramte alle uanset deres støtte eller mangel på samme til styret.

Iraks arabiske sunnimuslimer er ikke nogen homogen befolkningsgruppe. Geografisk er de spredt over Bagdad, de nordlige områder i og omkring Tikrit, Samara og alDur, stammeområderne i den vestlige del af landet samt de blandede befolkningsområder syd for Bagdad. Socialt er de meget forskellige: I Bagdad og de større byer udgjorde de kernen i den irakiske middelklasse under Saddam, og selv om meget har ændret sig siden 2003, er de stadig overrepræsenteret blandt den sociale og kulturelle byelite.

I de vestlige stammeområder derimod udgør de en skønsom blanding af fattige landarbejdere og bønder, lokale rigmænd og velhavende stammeledere. Politisk og religiøst dækker de et stort spektrum fra sekulære grupper over tværreligiøse partier til islamister og jihadi- ster, der er parate til at udføre voldelige handlinger i islams navn. Iraks arabiske sunnimuslimer er kort sagt en meget broget forsamling både økonomisk, socialt og kulturelt.

\section{Problemer efter invasionen}

Invasionen i 2003 medførte voldsomme forandringer for de arabiske sunnimuslimer. I kølvandet på den irakiske stats kollaps stod de nu uden ledere og dermed uden nogen til at tage over og varetage deres interesser i det nye Irak. Der var ingen institutioner, der kunne danne ramme om et nyt politisk liv, ingen eksilgrupper af betydning, der kunne vende tilbage og hjælpe med processen, og måske værst af alt - intet bud på, hvad der nu skulle bære den arabisk sunnimuslimske identitet videre. Den politiske og sociale identitet, der havde udgjort kittet mellem dem, var væk, og en ny skulle genopfindes from scratch.

Og siden invasionen har problemerne stået i kø. De arabiske sunnimuslimer har ikke blot mistet deres tidligere privilegier, men er også konkret blevet meget fattigere: De har mistet deres job i militæret, efterretningstjenesterne og partiet, og mange er blevet fyret fra andre job af personlige eller sekteriske grunde, eller fordi de står først i køen, når økonomien kræver nedskæringer.

Den manglende sikkerhed i landet har ramt sunnierne hårdt, både 
fordi indenrigsministeriets shiadominerede politi mange steder systematisk jagter sunnier og sætter dem i fængsel - det dokumenteres bl.a. af at arabiske sunnier er stærkt overrepræsenteret i de irakiske fængsler og nogle steder har man sågar oprettet hemmelige centre for sunnifanger, der tortureres og mishandles.

Mange sunnier, især i de vestlige stammeområder, føler at amerikanerne i særlig grad er ude efter dem med de voldsomme angreb fx på Falluja og de mange besværligheder, de udsættes for i dagligdagen af amerikanske soldater, hvilket nogle steder kan minde om regulær besættelse. Og så er de bange for fremtiden og for, hvad der skal ske, hvis Irak bliver en føderal stat med udbredt regionalt selvstyre: De frygter, at de vigtige olieindtægter så vil blive kanaliseret uden om de sunnimuslimske områder og gøre de arabiske sunnimuslimer endnu fattigere, end de er i dag.

Og der er i praksis meget lidt, almindelige sunnimuslimer kan gøre ved situationen - prøve at skifte navn så det lyder mindre sunnimuslimsk, købe sig til et falsk identitetskort der angiver shia som trosretning, og ellers holde sig indendørs for ikke at komme i problemer. Med mindre man altså engagerer sig politisk og deltager i det spegede magtspil, der kendetegner det nye irakiske styre, eller vælger at lægge kræfterne i en af de væbnede grupper, der ved hjælp af bomber, likviderin- ger og andre voldelige midler bekæmper de shiamuslimske og amerikanske fjender.

Der er et bredt udvalg af grupper at vælge mellem - al-Qaeda i Mesopotamien, Jaish al-Islam, Jaish Muhammad og Ansar al-Sunna for blot at nævne nogle - og her kan man både få afløb for vrede og frustration og tillige tjene gode penge, der kan holde familien oppe i en svær tid. Det er ikke underligt, at det er svært at få bugt med den sunnimuslimske modstand i Irak under de omstændigheder.

\section{Nye muligheder}

I det seneste års tid har der dog åbnet sig nye muligheder: I takt med de stigende uoverensstemmelser mellem væbnede sunnimuslimske grupper som $\mathrm{fx}$ al-Qaeda og sunnimuslimske stammeledere, der fra 2006 førte til stadig flere likvideringer af lokale stammeledere, borgmestre og andre, der ikke ville følge islamisternes påbud, har amerikanerne forstået at støtte disse stammer med penge og våben til gengæld for, at de så deltager i at opretholde sikkerheden og samarbejder med amerikanerne om at slå de islamistiske grupper ned.

Fænomenet der går under betegnelsen Sahwa, vækkelse, eller 'Berørte lokale borgere' som amerikanerne har valgt at kalde dem, har til formål at isolere al-Qaeda, forbedre sikkerheden og give stammefolk og al- 
mindelige sunnimuslimske irakere penge at leve for, og det er håbet på længere sigt at knytte disse grupper tættere til den irakiske stat, fx gennem militær og politi. Der skulle i dag være mere end 90.000 sahwaer, primært i Bagdad og i den nord- og vestlige del af landet, der for ca. 10 USD om dagen samarbejder med amerikanerne om at beskytte sunnimuslimske kvarterer og landsbyer, og det har utvivlsomt bidraget til den reduktion af volden, man har set i Irak siden efteråret 2007.

Og på det seneste har det rent faktisk ført til resultater: Omkring 5000 af disse sahwaer skulle i løbet af foråret 2008 være blevet indrulleret i de irakiske sikkerhedsstyrker, primært i det lokale politi, og selvom det har affødt en del modstand blandt shiamuslimske politifolk, der typisk anser sahwaerne for terrorister, som blot for en stund har skiftet side, har det utvivlsomt bidraget til at forøge stabiliteten: Sunnierne har brug for konkrete resultater i form af job og bedre leveforhold, hvis ikke de igen skal give deres støtte til al-Qaeda og andre voldelige grupper. Men der er stadig lang vej igen, før man når målet om at integrere 20.000 sahwaer i sikkerhedsstyrkerne og finde civile job til resten.

\section{De nye politiske ledere}

Siden invasionen i 2003 har sunnierne altså måttet kæmpe på mange niveauer for at holde sammen på liv og familie og skabe en dagligdag under helt nye betingelser. Og selv om mediebilledet både nationalt og internationalt primært har fokuseret på de væbnede gruppers attentater, død og ødelæggelse - den slags giver som bekendt gode billeder - har der også været bevægelse og udvikling inden for det politiske liv.

Efter den rådvildhed, der prægede de arabiske sunnimuslimer i tiden efter invasionen, er der efterhånden dukket en række nye ledere op af forskellig observans, der med større eller mindre held har forsøgt at varetage sunnimuslimske interesser. Det er selvsagt mere komplekst at beskrive end attentater og selvmordsbomber, men fortjener så meget desto mere opmærksomhed, som at det er herfra, håbet om en mere fredelig varetagelse af deres interesser skal hentes.

De nye politiske ledere er, ganske som den sunnimuslimske befolkning generelt, ikke nogen homogen gruppe. De kommer fra både sekulære og religiøse grupper og tilhører såvel byeliten som ulamaer og stammesheiker. Deres vigtigste opgave lige efter invasionen var at minimere det magttab, de arabiske sunnimuslimer havde lidt, og skaffe sig mest mulig indflydelse.

Og det lykkedes i begrænset omfang i den første tid: I den midlertidige regering, der blev etableret under ledelse af Iyad Allawi i juni 2004 og under stærk amerikansk kontrol, var fem ud af 25 ministre arabiske 
sunnimuslimer, herunder bl.a indenrigsministeren, og det var også en sunnimuslim, stammelederen Ghazi al-Yawir, der blev udpeget som Iraks første præsident.

I den overgangsregering, der fulgte i maj 2005, var der ligeledes fem sunnimuslimske ministre: Her mistede man ganske vist indenrigsministerposten, men fik i stedet forsvarsministeriet, og præsidentembedet måtte overdrages til kurderen Talabani, og al-Yawir måtte nøjes med en post som vicepræsident. Men det, der ifølge den israelske historiker Ronen Zeidel var mest karakteristisk for den periode, var, at de fleste af disse ministre primært var folk, der var vendt hjem fra eksil, og som derfor ikke var repræsentative for sunnibefolkningen som helhed.

\section{Religiøse rørelser}

I samme periode begyndte repræsentanter for forskellige religiøse grupperinger at markere sig politisk. En af de mest omtalte var Hayyat Ulama al-Muslimin, Rådet for Muslimske Lærde - en paraply-organisation af sunnimuslimske ledere, der forsøgte at balancere mellem rollen som talerør for sunnimuslimerne, om end de ikke havde ambitioner om direkte politisk deltagelse, samtidig med at de indirekte gav i hvert fald moralsk støtte til den væbnede modstand.

Mange af disse var begyndt deres politiske aktivisme i 1990'erne, hvor Saddam som reaktion på nederlaget i Kuwait og den voldsomme nedslagtning af det efterfølgende shiamuslimske oprør i det sydlige Irak havde kastet sig ud i en religiøs propaganda-aktion: Målet var at udbrede en økumenisk sunni-shiaislam, der kunne lægge låg på den voksende shiamuslimske bevidsthed i samfundet, og det foregik bl.a. ved at bygge moskeer, både i sunni- og shiaområder, uddele koraner og lade sig filme under bøn.

Det var også i den periode at det irakiske flag fik tilføjet allahu akbar som et tegn på styrets religiøsitet. Ifølge Zeidel og flere andre historikere førte kampagnen imidlertid blot til en voksende kløft mellem irakiske sunni- og shia-muslimer, hvor imamer af begge retninger prædikede deres egne versioner af islam og derved gav plads til en voksende modstand mod regimet.

Og det var nogle af disse imamer, der efter invasionen i 2003 begyndte at manifestere sig i sunnimuslimske organisationer, som fx Rådet for Muslimske Lærde. Og de havde i langt højere grad end de tilbagevendte eksilministre forbindelser til sunni-befolkningen.

En anden islamisk inspireret gruppering af sunnimuslimer, som dukkede op i de første år efter invasionen, var Hizb al-Islami al-Iraqi, Det Irakisk-Islamiske Parti. Det var oprindeligt dannet i 1960 som en udløber af Det Muslimske Broderskab i 
Egypten, men var blevet forbudt i $1961 \mathrm{og}$ havde været det frem til 2003. Mange af disse folk havde ligesom imamerne i Rådet for Muslimske Lærde opholdt sig i Irak under Saddam-styret og repræsenterede derfor også et alternativ til de hjemvendte eksil-ministre.

Og partiet klarede sig faktisk så godt ved det irakiske parlamentsvalg i 2005 , at det fik en vicepræsidentpost, der stadig i dag er besat med partiets generalsekretær Tariq al-Hashimi, samt to af de seks ministerposter, der tilfaldt sunnimuslimerne.

At partiet definerer sig som islamisk betyder dog ikke, i hvert fald på nuværende tidspunkt, at det religiøse helt dominerer partiets politik. Skal man tro al-Hashimi og andre partifolk, lægger partiet først og fremmest vægt på at skabe et nationalt og uafhængigt Irak med plads til alle, også shiamuslimer, og lægger dermed politisk afstand til alQaedas vision om et sunnimuslimsk kalifat i Irak.

\section{Bathpartiet}

Også tidligere Bath-folk har på forskellig vis søgt at sikre sig politiske indflydelse. En af de få ledende Saddam-folk som det endnu ikke er lykkedes amerikanske styrke at tage til fange, tidligere vicepræsident Izzat Ibrahim al-Duri, har siden 2003 forsøgt at videreføre partiet: al-Duri der siden 1970'erne har hørt til Saddams mest tro væbnere - bl.a. blev hans datter gift med Saddams ældste søn Udai i 1988 - skal ifølge flere forskellige kilder have overtaget ledelsen af partiet, og af det seneste kommuniké fra partiet, der er tilgængeligt på nettet, fremgår det, at han på en enhedskongres " $i$ et befriet område i Bagdad" med "22 irakiske modstandskampgrupper", der blev afholdt den 2. oktober 2007, skulle være blevet valgt "som øverstbefalende for en overkommando for Jihad og befrielseskamp".

Men hvor al-Duri ifølge nogle kilder i august 2007 skulle have frasagt sig samarbejdet med de irakiske alQaeda-folk og annonceret, at han var parat til at forhandle med det nye irakiske styre, har andre fraktioner af Bathpartiet, fx generalsekretær Ghazwan Kubeisi, offentligt fastholdt ønsket om at samarbejde med væbnede oprørsgrupper. Der ser således ud til at være en grundlæggende splittelse blandt forskellige fraktioner i Bathpartiet om partiets retning, og trods den mere lempelige lov om af-bathificering, som det irakiske parlament vedtog i februar i år, er det usandsynligt at nogle af disse nogensinde vil få plads i det etablerede politiske system.

Også en række enkeltpersoner begyndte at manifestere sig politisk efter invasionen: Tidligere ministre der havde trukket sig ud af Bathpartiet under Saddam, kulturpersonligheder og andre, der i sidste ende bedst kan beskrives som repræsentanter for store familier og stammer, 
begyndte langsomt at organisere deres baglande og fik efterhånden formet grupperinger, der lidt efter lidt tog form af partier: Partiet for National Dialog, Den Irakiske Folkekongres, Den Nationale Front for et Frit og Forenet Irak etc.

Et godt eksempel på en af dem, der har haft succes i processen og $\mathrm{i}$ dag er med til at tegne de arabiske sunnimuslimer politisk, er Saleh alMutlaq fra Hizb al-Hiwar al-Watani, Partiet for National Dialog. Han er født i 1947 i nærheden af Falluja og var som mange andre af de arabiske sunnimuslimske ledere tidligere medlem af Bathpartiet, men meldte sig ud i 1977. Han er uddannet agronom og har endda en ph.d. fra universitetet i Aberdeen, men slog sig siden med stor succes ned som forretningsmand.

Økonomisk har han klaret sig så godt, at det forekommer sandsynligt, at han må have haft gode forbindelser til styret, ikke mindst under sanktionerne op igennem 1990'erne.

Partiet for National Dialog er i dag Iraks næststørste sunnimuslimske parti og det femte største i parlamentet, og han selv er en af de mest fremtrædende sunnimuslimske ledere både nationalt og internationalt. Andre personer, der på lignende måde er trådt frem med stor gennemslagskraft efter 2003, er fx Adnan al-Dulaimi, der leder det største sunnimuslimske parti Det Irakiske Folks Råd, og som bl.a. har sit bag- land i den store Dulaimi-stamme, og Mahmud al-Mashhadani fra Det Irakisk-Islamiske Parti, der i dag er parlamentsformand.

Før 2003 var disse på det nærmeste ukendte i offentligheden, og netop den proces illustrerer meget godt, hvor nyt og spinkelt et grundlag de arabiske sunnimuslimske ledere agerer på.

\section{Den politiske proces}

Rådvildheden i de første år efter invasionen og spændingerne mellem de forskellige sunnimuslimske grupper om, hvilken taktik der ville medføre mest mulig indflydelse i det nye Irak, førte til boykot af det første parlamentsvalg. Det var en katastrofe, som hurtigt gik op for mange sunnimuslimer, der nu stod over for et parlament bestående af næsten udelukkende kurdiske og shiamuslimske repræsentanter med dagsordner, der var ganske forskellige fra de sunnimuslimske.

Parlamentets vigtigste opgave var at forhandle en ny irakisk forfatning på plads, der siden skulle til folkeafstemning, og derfor havde alle parter, herunder også kurdiske og shiamuslimske parlamentarikere, en vis interesse $i$ at drage sunnimuslimerne ind i arbejdet.

Der blev udpeget observatører for sunnierne, som kom med i det videre arbejde, og selv om det ikke førte til nogle sunnitiske fingeraftryk af betydning på forfatningen, al den 


\section{HELLE LYKKE NIELSEN}

stund at observatørerne i kraft af deres antal som regel blev stemt ned, lærte mange sunnimuslimer lektien: At der ikke er nogen vej uden om politisk deltagelse, hvis de vil maksimere deres indflydelse.

Det kunne man bl.a. konstatere af deres deltagelse i folkeafstemningen om forfatningen, om end langt de fleste stemte imod, og siden i det første regulære parlamentsvalg, der blev udskrevet efter retningslinjerne i den nye forfatning.

Op til parlamentsvalget i 2005 indgik flere af de sunnimuslimske partier koalitioner i forskellige kombinationer med det resultat, at den store sunnimuslimske koalitionsliste Jabha al-Tawafiq al-Iraqiyya, Fronten for Irakisk Enighed, der består af Det Irakiske Folks Råd, Partiet for National Dialog og Det Irakisk-Islamiske Parti, fik 44 af de 275 pladser i det irakiske parlament. Det førte til seks ministerposter, herunder forsvarsministerposten som dog er besat af en uafhængig kandidat, samt posten som parlamentsformand, vicepræsident og -statsminister - alt i alt ikke noget ringe resultat set i lyset af den svage udgangsposition, som de arabiske sunnimuslimer havde i 2003.

Det kan så godt være, at nogle sunniministre og parlamentsmedlemmer undervejs har trukket sig fra deres poster i et forsøg på at lægge pres på de øvrige grupper, ganske som fx de shiamuslimske repræsentanter for Muqtada al-Sadrs parti også har, men de er som regel enten vendt tilbage eller har sørget for, at andre sunni-repræsentanter har overtaget deres poster.

Det kan også godt være, at de ofte føler sig misbrugt som brikker i et politisk spil, sådan som det p.t. sker i sagen om henrettelsen af kemiske Ali, der skulle have været hængt for mange måneder siden, men som Maliki trækker i langdrag for at sikre, at endnu to af Saddams folk trods sunnimuslimske protester bliver henrettet i samme ombæring.

Alligevel har læren været klar: Det irakiske parlament er en vigtig kanal i den proces det er at skaffe sig indflydelse på egne betingelser i det nye Irak. Og det hellere med en gruppe ledere af blandet art, som har gode forbindelser til befolkningen, end med tilbagevendte eksilpolitikere.

Efter attentatet mod den gyldne moske i februar 2006, hvor sunnimuslimske grupper ødelagde en vigtig shiamuslimsk helligdom, har parlamentet haft svært ved at fungere i lyset af den voldsspiral, attentatet medførte. Derved har de væbnede sunnimuslimske grupper, man mener udøvede attentatet, bidraget til at spænde ben for det videre politiske arbejde og har sammen med generelle politiske spændinger mellem de forskellige etniske og religiøse grupper søgt at blokere for, at Irak kommer videre.

Der er dog sket forbedringer i løbet af 2008, hvor det bl.a. er lykke- 
des at få vedtaget et budget, en amnestilov samt en lov om af-bathificering, samtidig med at regeringen med en vis succes har slået ned på væbnede militser i både Basra, Bagdad og Mosul.

Men midt i det politiske virvar ser det ud, som om de sunnimuslimske politikere til stadighed gør sig overvejelser om, hvordan deres politiske indflydelse kan maksimeres. Det kan man bl.a. få et indtryk af, når man ser på de argumenter, de bruger for at fremme deres interesser. De ligner på mange måder dem, som også Saddam brugte i sin tid: At nedtone religion så vidt det overhovedet er muligt, for at mindske fokus på Iraks religiøse sammensætning, og optone en irakisk og arabisk nationalisme, altså tilhørsforholdet til de omgivende arabiske stater, Den Arabiske Liga og andre arabisksindede organisationer.

Der synes i dag at være en klar bevidsthed om, at antallet af potentielle sunnimuslimske stemmer aldrig vil give en vælgerandel, der kan udløse fordums tiders afgørende indflydelse.

Men ved at italesætte en irakisk fællesskabsfølelse og et tilhørsforhold til den arabiske verden kan man måske etablere en dagsorden, der kan hente støtte fra shiamuslimske arabere og sunnimuslimske kurdere, og derved give grundlag for at forhandle sig frem til større indflydelse, end deres antal berettiger.

Det modsatte, nemlig at optone den religiøse identitet, sådan som mange shiamuslimer og en del væbnede sunnimuslimske grupper gør det, kan kun føre til flere problemer og mindre indflydelse. $\mathrm{Og}$ det er jo god og sund politisk tæft, der peger fremad.

Om det så lykkes, er en anden sag.

Helle Lykke Nielsen, lektor, ph.d., Center for Mellemøststudier, Syddansk Universitet.

\section{Udvalgte kilder}

Claude, Patrice: Irak: les janissaires de l'Amérique. Le Monde, 19. marts, 2008 www.lexisnexis.com.proxy1-

bib.sdu.dk:2048/uk/nexis/search/newssubmitForm.do

Det Irakisk-Islamiske parti www.niqash.org/content.php? contentTypeID $=151 \&$ id $=1013$

Komiteen for et frit Irak: Den irakiske modstand danner Overkommando for Jihad og Befrielse www.fritirak.dk/artikler/nyheder/ 2007/1004_kommunike_overkommando _for_jihad.htm

Rubin, Alissa J.: Conflicts Deepen Between Local Iraqi Governments and U.S.-Backed Sunni Groups. New York Times, 10. februar 2008.

www.nytimes.com/2008/02/10/world/ middleeast $/ 10$ iraq.html?st=cse\&sq $=$ iraq $+\% 2 \mathrm{~B} 200$ $8+\%$ 2Bsunni\&scp $=14$

Zeidel, Ronen (2008): A Harsh Readjustment: The Sunnis and the Political Process in Contemporary Iraq. I Barry Rubin (ed) Iraq after Saddam. Under udgivelse. 